\title{
'Global nuts and local mangoes: a critical reading of the UNDP Growing Sustainable Business Initiative in Kenya'
}

\author{
Author: Catia Gregoratti \\ Email: catia.gregoratti@ manchester.ac.uk \\ Institutional Affiliation: The University of Manchester
}

\begin{abstract}
This article provides a conceptual and empirical assessment of UN brokered partnerships that seek to deepen or create inclusive and sustainable agricultural supply chains in sub-Saharan Africa. More specifically it appraises the decision-making mechanisms, processes of partnership brokerage and project implementation within the UNDP Growing Sustainable Business Initiative (GSB) in Kenya. The paper argues that the lack of bottom-up participation in decision-making mechanisms and the predominantly economic imperatives driving the partnership projects have failed to reach out to the partnerships' intended beneficiaries - Kenyan small producers of nuts and mangoes. In conclusion it is suggested that opening up the GSB platform might hold the promise of reconciling sustainable business models with (some) poverty reduction.
\end{abstract}

Keywords: UNDP, public-private partnerships, sustainable investment, Millennium Development Goals, poverty reduction, farmers.

Catia Gregoratti is a PhD Candidate in the Department of Politics at the University of Manchester. Her research examines whether the UN Global Compact fosters participatory forms of governance and interrogates the effects of its engagement mechanisms. She is interested in critical approaches to global governance and the political economy of public-private partnerships and corporate social responsibility.

\section{Introduction}

In recent years, the relationship between the private sector and development has witnessed a resurgence of interest within academic and policy-making circles. Corporate philanthropy, the traditional form of private sector assistance to many lowincome countries, development initiatives and government-led efforts, has been progressively amplified (Utting and Zammit 2006); new public-private partnerships between businesses, international organisations, donors, NGOs and trade unions have been formed in support of specific development priorities and the Millennium Development Goals (MDGs) and the practices of and pled ges to corporate social responsibility (CSR) are increasingly narrated within a developmental and progressive dimension. The intensification of these activities has also been accompanied by the emergence of a reinvigorated and recognisable consensus, namely one which views the private sector as a developmental agent by virtue of contributing to economic 
growth, creating jobs, raising income and empowering the poor by providing a range of products and services (UN Commission 2004; World Bank 2005; UNDP 2006).

Despite the steady proliferation of global partnerships and their increased localisation very little is known about the way in which partnership projects are formulated, how (or if) they affect their expected beneficiaries, and whether business realities and imperatives can be reconciled with the objectives of equitable and sustainable development (McFalls 2007). Based on primary research conducted in Kenya this paper offers a conceptual and empirical reading of the political processes and performance of partnerships brokered by the United Nations (UN) that primarily seek to deepen or create inclusive and sustainable agricultural supply chains in sub-Saharan Africa. More specifically, it appraises the local processes of decision-making, partnership formation and implementation within the United Nations Development Programme (UNDP) Growing Sustainable Business Initiative (GSB) in Kenya.

The Growing Sustainable Business Initiative was preliminarily conceptualised on the occasion of the UN Global Compact's second Policy Dialogue 'Business and Sustainable Development' and was officially launched in cooperation with UNCTAD (United Nations Conference on Trade and Development), UNEP (United Nations Environmental Programme) and UNDP at the Johannesburg Summit on Sustainable Development. At Johannesburg hopes were running high once Kofi Annan anticipated that the initiative would become one of the "most promising pathway[s] in overcoming the poverty trap....and give hope and opportunity to the world's poorest' (UN Global Compact 2002). In September 2002, UNDP was mandated the responsibility of developing and decentralising the GSB concept to its Country Offices. The GSB aims and objectives were later defined and elucidated in an official document co-produced by the UN Global Compact and UNDP. At this point, the overall contribution of the GSB platform was identified as 'facilitating sustainable business and investment by the private sector through a process of multi-stakeholder engagement with governments, civil society, the UN family and other development organisations' (UN Global Compact and UNDP). For the GSB the notion of 'sustainable investment' as sumes two specific connotations: it is understood as a standard business activity such as an investment, acquisition, new production or sale closely aligned with the MDGs, and it is a type of economic activity which is actively supported by state and non-state actors, including the beneficiaries of such interventions (Sandbrook 2002).

Operationally the GSB is coordinated at global, re gional and country levels. Globally a small team of UNDP advisors, based within the UNDP Business Partnership Division, are expected to encourage international companies to take action; they also assess the merits and weaknesses of local partnership proposals, manage country-level activities and share country experiences. Since 2007 the role of Business Outreach Coordinator and GSB Regional Coordinator were created as meso-level points of contact between the GSB headquarters in New York, the Regional Bureaux and the Country Offices. At country level, where the partnerships unfold, a GSB Delivery Mechanism comprising a GSB broker and a Coordinating Group are established in selected LDCs 'where stakeholders agree that there is a need for such programme and where the UNDP Country Office is committed to supporting it' (Day et al. 2005). 
Since its creation the GSB has expanded its partnership portfolio to twelve developing countrie ${ }^{1}$ across the continents of Africa, Europe and Asia. The initiative's projects are primarily market led; this means that agricultural projects and food chains development for those at the 'bottom of the pyramid' (Prahalad 2005) such as smallholders and rural poor are some of the principal areas of interest and potential intervention. In mid 2008, out of 48 local projects listed on the UNDP GSB website 20 focussed specifically on the development of local and global supply chains for fresh fruits, vegetables, nuts, seeds, diary, fish and one even proposed the establishment of a local fast food chain in Madagascar.

This paper provides a conceptual overview of the partnership rationale and sheds light on the criticisms that have been mounted against its assumptions and postulated effects. It then contextualises the initiative at the local level by looking at the actors that steer the meaning and determine the feasibility of sustainable business models for poverty reduction in Kenya. Thereafter, the paper narrates the unanticipated failure of two partnership projects targeting the export market for global macadamia nuts and the local market for mango fruit juice and discusses the implications of the se outcomes. The overarching argument that transpires from the research is that the unchallenged economic rationale driving the partnership projects has not reached out or significantly benefited their intended beneficiaries - Kenyan nuts and mangoes producers. In conclusion, it will be suggested that the potential of the GSB needs to be rooted in more open and transparent deliberation and implementation processes to ensure that some of the spoils of public-private interventions are shared more equally.

\section{The Public-Private Partnership Rationale}

\section{Partnerships and Participation}

The concept of partnership includes a variety of co-operative arrangements. Commonly it does not entail an exclusive relation between the UN (or other international organisations) and the private sector, other actors such as governments, NGOs, trade unions, consultancies and academia are encouraged to work to gether with businesses and the UN to formulate policies or undertake specific projects as to collectively 'share risks, responsibilities, resources, competencies and benefits' (UN General Assembly 2003:4). This is certainly true in the global context where partnerships are often justified as a means to narrow the democratic deficit in global governance (Reinicke and Deng 2000). Notions of inclusivity and participation are not confined to global decision-making processes, once global partnerships move from policy to implementation, particularly in developing countries, in principle, they are premised upon the assumption that 'beneficiaries', 'communities', or the 'farmers groups' agree to the objectives of the partnership and co-participate in its execution. The resonance of this rationale is based on the emergence of recent academic and policy thinking on 'stakeholder democracy' which relies on ideas such as input and output legitimacy to assess the democratic credentials and delivery capabilities of global and local public-private interventions (Bäckstrand 2006).

\footnotetext{
${ }^{1}$ As of mid-2008 the in itiative was active in Madagascar, Tanzania, Kenya, Zambia, Malawi, Macedonia, Moldova, Mozambique, Serbia, Turkey, Cambodia, Indonesia. The GSB platforms in Ethiopia, Angola and El Salvador were abandoned.
} 
However, behind ideas such as greater pluralism and participation concerns for power relationships are often eclipsed. Partnerships are not only portrayed as infinitely inclusive but they also assume that all the actors partaking in the arrangement are 'equal' and hold the same interests and expectations, thus conveying the impression that some form of agreeable outcome will be reached. This thinking has and can be challenged on several grounds. First, the terms underpinning a partnership can act as a powerful disciplinary force which determines who is a 'key' stakeholder and who is not. If, for example, a partnership is defined as a strategic relationship between businesses and an intergovernmental organisation the farmers groups or communities potentially affected by the partnership might not be identified as the right or legitimate stakeholders. Furthermore, it has been noted that those at the receiving end of publicprivate interventions often find themselves in a double position of disadvantage: they often live in remote locations away from the centres where decisions about their livelihoods are made and they lack the political and material resources to access such spaces (Zammit 2003; Newell 2005). In the instances where the beneficiaries of these development interventions are given voice concerns have been raised about their ability to shape or challenge the issues that are discussed and the objectives that are identified (Dolan and Opondo 2005), and the possibility of neutralisation and incorporation of critical alternatives within dominant discourse (Thomas $2000: 44$ ).

However, it is plausible to argue that such observations obscure a more nuanced conceptualisation of beneficiaries as agents. While farmers and the rural poor might not often be included in formal decision-making processes ultimately, if sufficiently organised, within the spaces where projects unfold they can object to decisions that might be perceived as detrimental to their welfare and values. Viewing rural communities as passive recipients of new forms of market-based development reinforces a deterministic logic of no alternative. Equally, pronounced and increasing evidence of 'lack of inclusion' can threaten the legitimacy of any public-private arrangement and potentially induce the creation of mechanisms for bottom-up participation and political representation for the less powerful and marginalised. Existing global and local partnerships arrangements brokered by international organisations do not embody the characteristics of the kind of democratic and egalitarian 'new multilateralism' envisaged by Cox (1997), however their tendency to replicate geographical and power imbalances leaves open the possibility for the contestation and transformation of public-private mechanisms of governance.

\section{Partnerships and the 'win-win' Common Sense}

The partnership rationale has gained prominence not only because of its inclusive features and its 'win-win' appeal, as the public and private actors involved in a partnership together with its intended beneficiaries stand to gain materially or in terms of reputation or efficiency (Nelson 2002). The efficiency and win-win rhetoric explicitly uttered within the partnership rationale acts as a discourse of selflegitimation which detracts attention away from the structural determinants that led to the emergence of these hybrid forms of governance. Against a background where states are retreating from their social obligations, operational partnerships have been conceived, and are commonly justified, as means to solve the inequalities ensuing from processes such as increased liberalisation, privatisation and competitive regulation but remain premised on the assumption that (more) market-based development and the creation of new markets in untapped areas will lead to greater 
prosperity (UNDP 2007). Noting the contradictory logic of this argument it has been suggested that partnerships leave intact the underpinning of the global neo-liberal order (Bull and McNeill 2007) and serve as instruments to widen and legitimise strategies of capitalist accumulation and its actors (Soederberg 2006).

A number of studies have appraised the more detailed consequences and implications of public-private partnerships for the practice of multilateralism and the way in which the development discourse is being recast. Bull, Bøäs and McNeil (2004) recount that the increased role of a broadly conceived private sector might lead towards a distortion in policy priorities, a reduction of developmental objectives to quantifiable targets as well as a geographical distortion of development interventions. However, rather than proposing that the multilateral system is being privatised, in a later publication, Bull and McNeill (2007) acknowled ge that multilateralism, can, under certain circumstance, modify the practices of private partners as to reconcile developmental goals with the needs of the private sector to be recognised as socially responsible. Whilst this reading wants to recognise the agency and leverage of international organisation it does not explicitly recognise that public-partnerships and other voluntary pled ges in support of corporate social responsibility (CSR) might enhance the structural and discursive power of businesses (Fuchs 2007) and legitimise their authority as agents of development. Businesses gain moral standing from the association with intergovernmental bodies as the effects of their activities and commitments to CSR are sanctioned as 'positive', 'developmental' and 'empowering', and also benefit from wider access to political network and funds.

What are the consequences of market-based public-private intervention for the beneficiaries they intend to serve? Newell (2005: 556) notes that corporate social responsibility and public-private partnerships can work for some people, in some places and for some time. When such interventions work and appear to achieve economic objectives such as offering employment opportunities, income and market linkages other contradictions re-surface. Dolan (2005) finds that genuine improvements in the working conditions of urban dwellers and rural poor might be attained but they often come at the cost of displacing alternative conceptions of economic and social life. Referring specifically to the notion of ethical trade and sustainable business practices she argues that they "not only exclude African (or otherwise 'local') constructions of social organization but also privilege the labour formations and production systems of advanced ind ustrial economies, as rights can only be claimed through capitalist wage employment' (Dolan 2005: 382). However, it is important to note that partnerships might never move from the stage of conceptualisation, they can be abandoned at any point in time for lack of funding, commitment or because the expectations of economic returns do not materialise. In such circumstances, unless seed investments in organising, training or infrastructures have been made, the 'beneficiaries' gain little and lose their title.

\section{Researching Public-Private Partne rships in Kenya}

This research article critically examines the claims of inclusivity, political processes and outcomes of two public-private partnerships brokered as part of the UNDP 
Growing Sustainable Business Initiative in Kenya. ${ }^{2}$ It does so by analysing qualitative research material that was collected in Kenya between June and July 2006, follow-up email correspondence and additional desk-based research conducted between 2007 and 2008. In the first part of the paper I specifically draw on semi-structured interviews that were conducted with civil servants and temporary staff at UNDP Kenya and all the active members of the GSB Kenya Coord inating Group. The elite interviews with these members focussed primarily on the reasons for partnering with the UNDP, the perceptions on the legitimacy and effectiveness of the initiative and the experience of partaking within the decision making group.

In the absence of previous research on the initiative the insights gathered in the first phase of the field trip heavily guided the selection of the two partnership projects appraised in this paper. There is often a tacit disjuncture between the official claims emanating from the websites and press releases of international organisations and the actual practices of public-private partnerships formation and evolution. ${ }^{3}$ The actual status of the partnerships could only be verified with the GSB Broker, the gatekeeper, who suggested that whilst it was too premature to investigate recently endorsed projects (See: Annex 1), or de- linked projects, the partnerships respectively led by Global Entrepreneurs and the Kenya Gatsby Trust (KGT) were the only ones that had made substantial progress.

Information on the two case studies selected were elicited through in-depth interviews with executive members and project managers, documentation supplied by the two lead organisations, update reports presented to the UNDP as well as the official minutes of the Coordinating Group meetings. Whilst the narratives presented in this paper rely primarily on the accounts of 'elites', the research also sought to apprehend the perspectives of a group of farmers. A three days visit to Embu was facilitated by Global Entrepreneur's Food Engineer. In the rural periphery of the town semistructured interviews were conducted with the management of Mt. Kenya Nuts and smallholders, namely fifteen members of ten households living in close proximity to the factory. The interviews with the farmers sought to determine whether the beneficiaries were aware of a partnership taking place, whether any changes had ensued since the partnership officially began in 2005, and what issues were affecting the livelihood and welfare of the producers. A commensurable visit to the expected beneficiaries of the KGT-led partnership could not be organised because at the time when the field-trip was conducted the target group of the intervention was changing. Rather than constituting a hindrance to the research this has been effectively treated as a clue to illuminate how beneficiaries are selected and for what reasons.

\footnotetext{
${ }^{2}$ This article derives from research material elicited for a wider research on the UN Global Compact, an initiative which is commonly portrayed as the premier global public-private partnership. Whilst conducting qualitative interviews in New York in December 2005 a nu mber of UN civil servants suggested looking more closely at processes of partnership formation and implementation in support of the MDGs at country level. Kenya and Tanzania were identified as locations where I could investigate the politics of forums such as the UN Global Compact Local Network Kenya and one of the Co mpact's ancillary initiatives, the Growing Sustainable Business Initiative, which operates in both countries.

${ }^{3}$ This is not to say that the information is not accurate, sometimes it is simply not updated because of lack of personnel and resources - a commonly acknowledged problem in UN Country Offices.

However, whilst conducting research on the GSB it was also found that once the partnerships database are updated 'failed' partnerships are removed without explanations as to why specific projects were abandoned or de-linked from the GSB.
} 
The 'case study' method employed in this research paper has culminated in a two-tier analysis which discerns the hierarchies and power-relations at work within the GSB Kenya and the politics of partnerships formation and evolution. Such method has been preferred not only for of its explanatory qualities (Odell 2004) but also because it 'can expose tensions, strengths, weaknes ses...or even contrad ictions' (McFalls 2007: 89) in new forms of development interventions as they are rolled out from global institutions throughout the developing world.

\section{The Growing Sustainable Business Initiative in Kenya: Actors, Processes and Projects}

Following consultation with the Kenyan government, the private sector, the NGO and the donor community, UNDP in partnership with UNIDO (United Nations Ind ustrial Development Organization) and the ILO (International Labour Organization) launched the Global Compact and the GSB in Kenya on the $3^{\text {rd }}$ of May 2005. Both initiatives officially took off at the same time, however while the UN Global Compact Kenyan network was only established two years later, the GSB had already identified and presented to an invited audience three partnership projects and was keen to establish a Coordinating Group as soon as possible. Although the GSB broker was expected to run and coordinate both, existing Kenyan Global Compact's signatories (i.e. Tetra Pak and Vestergaard Frand sen) were encouraged to conceptualise and initiate sustainable business projects, while companies that expressed an interest in the GSB did not have to sign up to the Global Compact or, at times, they were not even made aware of the Compact and its principles. The initial, almost exclusive, focus on the systematic development of the GSB in Kenya was not solely based on the need to show that the idea was viable and 'pro-poor' but also because pushing two separate initiatives was proving to be an onerous task for a single civil servant.

\section{The Brokers}

Within the GSB mechanism and processes, the role of the broker is crucial in defining the 'success of the initiative' (UNDP 2007). The broker is not only expected to identify and coordinate individual projects while minimising the risks and cost associated with an investment he/she is also expected to make sure that these projects have a clear development dimension and are aligned with the goals of the UNDP, particularly the MDGs. In Kenya a new GSB broker was appointed on a yearly basis; the first two brokers fitted within the general UNDP job description of a candidate with extensive experience in the private sector, the capacity to provide analysis of business models including investment analysis and financial modelling, and the ability to convene coalitions of partners. Both brokers worked for a number of years in the private sector and although interested in development they did not have any experience of poverty reduction strategies and interventions. An interview with a broker confirmed that the kind of development sought after by the GSB was primarily, if not exclusively, economic, once a GSB civil servant stated that 'our priority is to develop new markets, creating employment and providing income...development will trickle down' (Interview, UNDP, 6 July 2006).

Brokers are also expected to establish the Coordinating Group, identify business partners interested in developing a sustainable business projects and forge linkages between busines ses and local NGOs. The ability to act as a nodal point and 
partnership broker appears to necessitate an in depth knowledge not only of local market conditions but also of the various development institutions, groups and actors working in the country and often carrying out work away from the capital city where the UN compound is based. Although UNDP Kenya had a long tradition of collaboration with a wide range of local private and public groups all the appointed brokers have been foreign nationals who, upon appointment, have been required to map and thereafter make contact with 'key' partners.

\section{The Kenyan Coordinating Group}

The decision-making mechanism through which the GSB's targets are set, projects approved, and consensus on the meaning of sustainable business is reached, is the GSB Coordinating Group - an umbrella group made of government representatives, businesses, NGOs, international organisations and relevant bilateral and multilateral donors (UN Global Compact and UNDP 2002). The Kenyan Coordinating Group was established shortly after the GSB's launch, its members had a history of institutional affiliation with the UN or were invited to become members by virtue of the scale of their involvement in private sector and development types of activities. The identification of the right or appropriate stakeholders did not seem to conform to the aspiration of closing the democratic deficit in global governance; rather, it mirrored concerns such as status, previous contacts with UNDP Kenya and the willingness to participate and devote time to the GSB processes. Official documentation suggests that these groups should be 'inclusive' however, on closer inspection, those who partake in formal decision making processes are largely private sector representatives, and a handful of local organisations with long-standing interests in facilitating market expansion and deepening ${ }^{4}$ such as African Management Services Company (AMSCO) and the Kenya Gatsby Trust. The participation of donors, international development institutions and NGOs was minimal whereas trade union and the Kenyan National Federation of Agricultural Producers had been simply forgotten (Interview, UNDP, 6 July 2006). Furthermore, despite recognising the importance of including government officials within the coordinating mechanisms, the participation of public officials was limited and inconsistent.

When questioned about the representativity of the group the emerging consensus was that the supposed beneficiaries of the partnerships did not need to be included in deliberations. One member of the Coord inating Group commented that 'when you bring the farmers in they tend to bring their own interests and they are not very objective. We, on the other hand have no direct or vested interest, we think about the whole community and not about individuals...I would feel as if I let the farmers down if I did not attend a meeting' (Interview, KGT, 14 July 2006). Another member from the private sector added that 'the Coordinating Group is broad enough and if a labour union was to be invited to join they would not represent the non-unionised farmers' (Interview, Export Promotion Council, 20 July 2006). Likewise, the GSB broker never questioned whether the group could be made more 'inclusive' or whether the projects' beneficiaries should be consulted at any point of the partnership processes, preferring instead to focus targets such as number of projects, commercial feasibility

\footnotetext{
${ }^{4}$ Ronen Shamir (2004) defines these organisations as Market Non-Govern mental Organisations (MaNGOs).
} 
and potential outcomes rather than developing participatory mechanisms of deliberation and implementation.

\section{Identification, Endorsement and Project Portfolio}

During the early stages of institutional development UNDP New York contacted various foreign companies and multinational corporations who would be potentially interested in developing sustainable business models in Kenya and then passed on the details to the GSB Kenya. At the same time, the local broker was also urged to contact foreign companies and small and medium size enterprises (SMEs) in an effort to establish a preliminary project portfolio. Both strategies showed early signs of success which was further amplified once the Coordinating Group member started to 'spread the word' about the GSB business proposition and the possibilities of co-fund ing it offered for market research and socio-economic feasibility studies. The second broker was determined to reach out to a wider audience and, in collaboration with a small team of UNDP interns, contacts with the local media were made and boisterous articles on the GSB appeared on the Kenya Times and the Daily Nations in 2006, which were later followed by a nomination at the Africa Investor Awards 2006. At this point the broker was no longer on the lookout for potential business partners as the UNDP was being directly contacted by local enterprises (Interview, UNDP, 6 July 2006).

As expression of interest started to increase the GSB Kenya pioneered the development of more specific guidelines to as sess the economic and social impact of proposed partnership projects. Initial screening was undertaken by the broker on the basis of a clear delineation of the business case and social impact of each initial proposal, 'a project which does not present a convincing business case, despite having strong social impact, cannot be considered a GSB project. Likewise, a project that makes business sense but cannot sufficiently demonstrate sustainable development impact will not be endorsed by the GSB' (Personal Communication, 7 July 2006). In order to be considered for formal GSB endorsement and potential co-funding every business was requested to outline in writing or verbally present to the Coordinating Group the project description, the business case and financial plan for engaging in a new venture or market development as well as indicating its supposed de velopment impact, which for the majority of proposed projects equated to an assumption of potential rise in employment and income (See: Annex 1). It is important to note that businesses were ultimately left with the responsibility to select the supposed beneficiaries independently of whether these were 'poor' or not.

Between 2005 and 2007, 18 projects were presented and positively reviewed during the bi-monthly Coordinating Group meetings (See: Annex 1). Eight partnerships were subsequently de-linked from GSB Kenya and pursued without GSB assistance because companies did not need the platform and co-funding or were subsequently moved to other countries. For example, Tetra Pak moved to the GSB Tanzania to explore the development of an integrated supply chain for UHT milk. Out of the remaining (officially endorsed) ten partnerships, those 'dumped from UNDP New York' with MNCs such as Voxiva, Freeplay and Microsoft did not take off due to low commitment, diverging interests and communication problems arising from the fact that some of the companies did not have offices in Eastern Africa. 
Unlike the original expectations, the currently active seven partnerships are those which might also hold the greatest developmental potential not only because they are led by Kenyan companies but also because they intend to create explicit linkages with local firms and, in the case of agricultural interventions, small producers (Jenkins 2005: 252). The preponderance of proposed and existing projects targeting the agricultural sector and smallholders is not casual; agriculture and food production constitute the backbone of Kenya's economy with more than two million outgrowers, labourers and brokers working to meet the demands of local consumption and the export market (Dolan and Humphrey 2004; Brown and Sanders 2007). However, the sectoral concentration of agricultural and food projects did not arise primarily out of concerns for poverty mitigation in rural areas, where poverty is highest and agricultural production is the main form of subsistence (Freeman, Ellis and Allison 2004), but because market demands and research e stablished that substantial returns could be made from smallholders' flexible and cost-efficient production.

\section{The Growing Sustainable Business Initiative in Action: Global Nuts and Local Mangoes}

How do the GSB sustainable business models work? The approval and endorsement of two distinct projects, a global supply chain for macadamia nuts and a local supply chain for mangoes occurred in 2005; they were amongst the first group of projects formally endorsed by the GSB Kenya and the Coordinating Group and, as 2008, they are both still listed as 'active' in the GSB global website as well as the UNDP Kenya website. Although the GSB Kenya is still developing and testing the brokerage of partnerships, project implementation and supervision, the narratives and developments of both projects indicate that global and local market demands have resulted in both projects failing to bear any financial and non-financial benefits to their expected beneficiaries - the smallholders in Embu and Malindi.

\section{Global Entrepreneurs, Global Nuts and Macadamia}

Between 2002 and 2004, as part of its expansion strategy, the international trading company Global Entrepreneurs International (GEI) ${ }^{5}$ set up a new office in Kenya Global Entrepreneurs Africa - in an effort to open up opportunities for the export of locally produced spices, beans and nuts. In 2005 the company identified macadamia nuts as the prime product for its export activities. Research undertaken by the company showed that local production for exports had doubled between 2000 and 2005 raising from 4,900 metric tons to approximately 10,000 metric tons and that the local production and processing market in the hands of Kenya Nut Company had the potential to be made more competitive. Global forecast indicated not only that macadamia constituted $2 \%$ of the world market for nuts but also that Northern demands for healthier food products were set to rise. The global scoping exercise also found that the global market for the product was dominated by Australian and South African producers, and that highly fluctuating prices were primarily dictated by criteria such as quality and demand. Within this context the idea of developing a value-added niche market for organic macadamia nuts and oil emerged and the export

\footnotetext{
${ }^{5}$ Historically the GEI was established by AIESEC Executives and it co-funded by the Norwegian Agency for Development Cooperation (NORAD).
} 
company Global N uts was established in early 2005 as a Kenyan incorporated company wholly owned by Global Entrepreneurs Africa.

Once established, Global Nuts started to look for producers with sufficient supplies to initiate its export activities and establish market linkages with wholesale buyers in Europe. During this phase, the company was contacted by the financial arm of Embu Farmers Co-operative Society which owned Mt. Kenya Nuts - a factory which buys macadamia nuts from 4000 farmers, processes and packages the nuts for sale to the international market. The factory, endowed with the technology to dry, grade, crack and package the nuts was not able to sell an overly generous surplus stock and, unable to meet loan re-payments it was risking bankruptcy and delayed payments to farmers. Global Nuts decided to source macadamia nuts from Mt. Kenya Nuts who "promised extremely optimistic supply forecast' (Interview, 13 July 2008), however the first transactions were hampered by the fact that Northern buyers did not have much confidence in the quality of Kenyan nuts and Mt. Kenya Nuts was unable to deliver the specified quantity of 14 containers. By November 2005, thanks to a cash advance only 4 containers were shipped to Europe and the Middle East. Visits to the factory established that much of the inventory was made up of raw nuts (e.g. nuts originating from shaken trees), purchases of nuts from farmers and middlemen were made on an ad hoc basis, the equipment was not being used correctly as the factory staff did not know how to operate the machines and the factory was in need of thorough clean up. Global Nuts determined that capital and human resources were needed to resuscitate the fortunes of its main supplier.

Contacts had already been made with the GSB in the summer of 2005 but neither Global Nuts nor the GSB broker could clearly determine how the UNDP could provide assistance, despite this the project was included in the portfolio's pipeline. The definition of a GSB sustainable business model with a development dimension occurred much later, by accident rather than design. While travelling for business Global Nuts was introduced to a Japanese consultant ${ }^{6}$ from HardNut International who had extensive experience in the Kenyan macadamia ind ustry and had worked for Kenya Nuts Company ${ }^{7}$ where he oversaw propagation, grafting, harvesting, nuts collection and processing. With the possibility open of having a consultant to provide advice and production and processing, while the marketing was already being developed by Global Entrepreneurs (i.e. website, packaging, publicity, trade fairs), Global Nuts re-approached the GSB with a preliminary plan for co-funding the consultancy service and was encouraged by the GSB broker to finalise the project proposal.

The ex-ante project proposal was developed entirely by Global Nuts with input not being provided by smallholders or the factory board whose relations with Global Nuts were increasingly strained by signs of internal instability and poor management, the refusal of Global Nuts' financial tendering and the little room for manoeuvre accorded to a production and quality consultant installed in the factory by Global Entrepreneurs. The project proposal however, had, according to the GSB broker, a 'strong' business and development proposition (Interview, 13 July 2006). The

\footnotetext{
${ }^{6}$ The bilateral relations between Japan and the Kenyan government dated back to the 1970s when Japan's funding was instrumental in creating the institutions, capacities and infrastructures needed for the creation of a Kenyan market for macadamia.

${ }^{7}$ Global Nuts' main co mpetitor.
} 
business case was centred on the assumption that increased quality, direct supply from farmers as opposed to middlemen and improved knowledge of manufacturing processes and the long-term plan for an organic niche market would have an impact on macadamia prices; however it was acknowledged that globally more suppliers were entering the market. The development case had two components. First it assumed higher and more predictable sources of income for the co-operative's farmers through higher dividends and the premium ens uing from organic certification and higher income opportunities for non-cooperative farmers. Second it included, with little details and no clear partners in place, capacity building elements such as education on the industry, sustainable husbandry, ${ }^{8}$ loyalty programmes and the organisation of farmers into groups (Personal Communication, Global Entrepreneurs Project Proposal, 14 July 2006). When it was clarified that the consultant's role would be that of determining profit sharing along the supply chain and designing training and loyalty programmes for 'the farmers', in June 2006 the Coordinating Group approved the project and a sum of $\$ 10,000$ was set aside to co-fund ${ }^{9}$ the consultancy (UNDP GSB 2006 a).

At the time when fieldwork was conducted in Embu, Global Entrepreneurs' Food Engineer had prepared a detailed report on the numerous deficiencies that were hindering the production processes but was not allowed to implement any changes as the factory did not grant her permission to do so. Mt. Kenya Nuts' Production Manager, who agreed to be interviewed outside the factory gates stated that 'we are a young factory, we need help but the board of directors is too political and it is unlikely anything will change' (Interview, 27 July 2006). The farmers interviewed for this study were wholly unaware of any partnership project taking place and had not noticed changes in their relationships with the factory. They continued to supply intermittent quantities of nuts to the middlemen and/or the co-operative for 15-20 $\mathrm{KSh} / \mathrm{Kg},{ }^{10}$ while intercropping coffee, beans, maize, bananas, and cassavas for income and consumption purposes. Trust that macadamia would provide higher income was dismissed in the light of the low number of trees per household (3 to 8), limited cultivation space, and the seasonality of the fruit. Such disillusionment was vividly expressed by one farmer who stated '...I prefer to give macadamia to the children instead of selling it...' (Interview, 26 July 2006). However, all the interviewees concurred that they would be better off if the co-operative paid a fairer price for the nuts, which was determined at around $80 \mathrm{KSh} / \mathrm{Kg}$.

In Nairobi, while Global Nuts was already investing in its own processing factory in the capital's export processing zones, it continued to hold talks with the GSB Coordinating Group about Mt. Kenya Nuts and the Embu farmers but only signalled that for financial reasons the factory was unable to produce nuts for the new season (UNDP GSB 2006 b). The Coordinating Group agreed that the Minister of Cooperatives should be consulted but even with this intervention the project terminated in 2007 when the UNDP determined that 'the co-operative, despite initial assurance, was not interested in providing benefits to its members' (UNDP 2007:47).

\footnotetext{
${ }^{8}$ The sustainability aspect of the project was not only relegated to 'strict environmental and ecological guidelines' free from chemical and pesticides (Personal Communication, Global Entrepreneurs Project Proposal, 14 Ju ly 2006), but it also envisaged the recycling of the nuts' shells and use them as fuel.

9 Additional funding to follow up on the consultant's recommendation was expected to come from NORAD (US\$20,000) and Global Entrepreneurs Africa in the form of human resources (US\$22,535).

${ }^{10}$ The a mounts varied depending on the dis tance to the collection centres and the need for cash.
} 
Global Nuts continues its operations in Kenya, has signed up to the local Global Compact network, and it is still listed within the GSB project portfolio. However, in order to ensure the survival of its own business it withdrew its 'assistance' to Mt. Kenya Nuts and the co-operative's farmers. The GSB could not explain how the project could have been run differently, but it is plausible to infer that issue of ownership (Witte and Reinicke 2005:44-46) was not adequately addressed and failure to bring Mt. Kenya Kenya Nuts and the beneficiaries to the discussion table might have largely contributed to the demise of the proposed project.

\section{KGT, Kevian and mangoes}

Unlike the partnership initiated by Global Entrepreneurs, the idea of initiating a supply chain for mangoes departed from work that the Kenya Gatsby Trust had undertaken in support of facilitating market access for small-scale mango producers in the coastal region of Kenya. The Gatsby Trust's interest in mango production developed before the GSB was created. The overarching objective of the Trust, in fact, is to catalyse sustainable wealth creation in the poorest areas of Africa and the coastal districts of Malindi and Magarini are two of them. In 2001 a series of participatory appraisal studies were initiated and found that in the region mangoes were overproduced and that they were not being sold due to poor quality (i.e. the fruits were infested) and little access to markets, farmers were not organised, a lack of secure sources of income incurred exploitative transactions with middlemen with each fruit being bought for as little as KSh 1, and that Minis try of Agriculture had provided little or no extension services or post-harvest facilities to smallholders.

Between 2003 and 2005, with funding secured from the Gatsby Trust and the JJ Charitable Trust, KGT first encouraged mango growers to engage in common marketing efforts and improved techniques, second, under an arrangement coord inated by the local KGT office, 61 youths were privately trained by Bayer and the Kenyan Agricultural Research Institute (KARI) in spraying trees against pests while more than 200 farmers received advice on pruning and how to minimise the risk of infection (Gatsby Trust n/d). Within two years farmers were organised into13 groups with membership of 253 and 26 private extension service providers, furthermore thirteen demonstrations were set up, a system of farm input supplies with a credit component was put in place and a private extension manual was developed by KARI as part of the capacity building elements of the project; by 2005 KARI also enabled one group to receive quality assurance certification. During this first phase, funding from the $\mathrm{S}$ wiss sustainable development foundation Bio Vision also enabled a parallel research partnership between KGT and the International Centre of Insect Physiology and Ecology (ICIPE) in order to de velop a non-chemical pest spray based on natural ingredients such as peppers and elements of the indigenous neem tree.

Once the farmers were trained and organised and the quality of fresh mangoes was deemed suitable for sale, even if quality assurance mechanisms needed to be better defined, grading was not possible and collection points remained rudimentary, the second phase of the project went ahead and focussed on linking the local mangoes market with buyers. Amongst the interested buyers contacted by KGT figured Del Monte and local supermarket chain Uchumi. The former did not finalise the agreement, however Uchumi did buy some of the mangoes but when it went bankrupt the farmers were temporarily left with no buyers. In a moment of 'panic', whilst 
looking for alternative buyers in 2005 the KGT was introduced to the GSB and the first broker put KGT in touch with the Nairobi-based juice producer Kevian (Interview, KGT, 14 July 2007). At the time, Kevian had invested in a fruit processing plant in Thika (50 Km North of Nairobi) in an effort to decrease high inventory costs and avoid heavy taxation on imported concentrate by producing its own concentrate for local consumption and export. The contacts established by the GSB proved to be successful as Kevian was interested in sourcing local mangoes; hence KGT took the lead in facilitating a meeting between Kevian, 26 group leaders and 3 extension workers with which the is sues of quality, quantity and delivery dates were discussed.

The project was discussed and formally endorsed by the GSB Coordinating Group in October 2005 even if the factory had not been completed and uncertainties remained over who would supply mangoes to Kevian, though KGT hoped that a deal with the smallholders in Malindi could be finalised. This was reflected in the project description which vaguely mentioned that 'the key beneficiaries would be small scale farmers in specific districts in the Eastern, Central and Coastal and Rift Valley areas' and in the addition of Deutsche Gesellschaft für Technische Zusammenarbeit (GTZ) to the partnership ${ }^{11}$. According to the GSB broker, the proposal also lacked overall specificity, as it was not clear whether the project would be economically viable and how the quality of the mangoes would be improved (Interview, 16 July 2006). When Kevian attended the GSB Coordinating Group meetings clearer information on the direction of the project could not be obtained but the company continued to build a case for the need to lobby the government to remove excise duties on tax and water (UNDP GSB 2005).

In summer of 2006 the factory was almost completed and with a mango creamer ready to be installed negotiations with the original beneficiaries, the producers in Malindi, were re-opened. Kevian was prepared to pay $13 \mathrm{Ksh} / \mathrm{Kg}$ or $6.5 \mathrm{Ksh} /$ per mango, however it also expected for the producers to pay for transport costs which, including packing, loading and unloading were estimated to be as high as $5 \mathrm{Ksh}$ per mango thereby making a net gain of $1.5 \mathrm{Ksh} /$ per mango. Even though extensive research with the eight most reliable transport companies was conducted no deal was struck. As the KGT project programme officer stated:

'...If Kevian is not prepared to pay for the transport costs then the partnership would have to come to an end. The export market is much more lucrative as the farmers would gain a net profit of $6 \mathrm{Ksh}$ per $\mathrm{kg}$ of mango and the farmers would not have to incur transport costs. The only way for the economic partnership to be resurrected would be for Kevian to consider absorbing the transport costs, however Kevian is not a philanthropist and this alternative would have to make business sense, especially considering the ascending costs of fuel. At the bottom line of the partnership economic considerations need to be prioritised. The processing factory is $50 \mathrm{~km}$ away from Nairobi...10 hours drive away from Malindi...'

\footnotetext{
${ }^{11}$ GTZ, with self-funding for the project (GTZ PPP Fund), was entrusted with the responsibility of looking for more suppliers of high quality mangoes in the Central districts
} 
Despite the setback, and with no particular concerns for the smallholders in Malindi which continued to be independently assisted by $\mathrm{KGT}^{12}$, the GSB continued to support the Kevian project. In 2006 members of Coordinating Group visited the factory and were pleased 'with the opportunity to see the factory processing passion fruit and the state of the art equipment' (UNDP GSB 2006 b). In the meanwhile GTZ was able to trace mango producers closer to Thika and the beneficiaries were reidentified according to cost and quantity criteria, and the districts of Emebere and Embu were chosen to start anew a farmers' training programme. However, even if new smallholders were identified and the Ministry of Agriculture had agreed to offer extension services, there was no defined capacity building plan in place that would have ensured that the 'new beneficiaries' would be in a position to meet the quality and quantity demands imposed by Kevian.

\section{Discussion: the Implications of Market-Based Development Strategies}

Both case studies illustrated that the project definition and the project direction was ultimately defined by businesses and dictated by economic priorities with UNDP not raising questions about the marginalisation of the beneficiaries, their role in the projects, their expectations and knowledge. At no point were the intended smallholders invited to the discussions taking place at UNDP and empowered to make basic decisions about their livelihoods - economic opportunities were catapulted from the outside and changes to the project plans were defined in Nairobi. Omitting the question of who defines and drives sustainable business projects is to reinforce the apolitical notion that partnerships are 'neutral', infinitely inclusive and that all the 'stakeholders' and beneficiaries involved have an equal say. This observation echoes the arguments put forth by an emerging body of critical scholarship on corporate social responsibility and public-private partnerships which has observed that in multistakeholder forums and meetings those who normally don't have a voice in society are also the ones excluded from the discussions (Prieto-Carrón et al. 2006: 984).

Second, the question of distribution of benefits deserves some attention. As Blowfield (2007) asks, what assumptions can be drawn about the impact of these interventions? Within the GSB model, lead companies gain from the association with the UNDP name and the publicity that comes with it, here the reputational gains are substantial and should not be underestimated. As the cases of Global Entrepreneurs and Kevian testify the GSB opened up to businesses opportunities for networking and partnerships formation, it offered free guidance on the development of a business plan, and was instrumental in allowing businesses to bid for or acquire public or private funding and financing. The gains accruing to the private sector are not only implicit in the GSB value-proposition but are also cultivated because failing partnerships could potentially undermine the entire initiative, its expansion plans and donors' funds. (In)avertedly the GSB platform also created a political space, at the Coordinating Group meetings, where, on occasions, the private sector could discuss the kind of policy changes, which would be required to foster more profitable and efficient economic transactions (i.e. lower taxes).

\footnotetext{
${ }^{12}$ KGT linked the smallholders to a Belgian wholesaler and was actively looking into donor's fund to set up a pulp-processing factory in Malindi, at the same time it had started to evaluate the possibility of establishing a more lucrative market for dried mangoes.
} 
Similar or commensurable benefits have not been shared with smallholders. At the bottom of the supply chains some opportunities for smallholders have been created and equally removed. The viability of a sustainable business model is, first and foremost, dependent on the market imperative of profit maximisation. Beneficiaries are 'picked' because they can produce what a company wants at a price and quality that is deemed favourable by the buyer. Howe ver, even if the prices paid tend to be higher than what middlemen offer, buyers have the power and capacity (i.e. resources and networks) to relocate their 'developmental responsibilities' towards more costefficient producers, as illustrated by the experience of Kevian. Interviews with the farmers in Embu suggested that smallholders' wages continued to be determined by formal and informal market transactions; employment opportunities remained seasonal and dependent on fluctuating demand. Incomes were dependent not only on old and new market linkages but also on family remittances, crops' diversification and, for some, the identification of work opportunities away from the country side. Hence, even the modest contributions that isolated sustainable business model and the GSB claim to bring in the advancement of the MDGs or sustained poverty reduction can be open to challenges.

This however, is not to dismiss entirely the potential value that sustainable business models might yield for the processes of development and the livelihood of smallholders. The new GSB guidelines for agro-food partnerships specify that several capacity building components should be identified prior to the development of a supply chain and suggest that quality and productivity improve ments, building trust amongst smallholders and organising farmers groups should be explicitly integrated within project proposals (UNDP 2007:43). With busines ses or governments not always in a position to offer such services the delegation of this respons ibility is expected to fall in the hands of MaNGOs such as GTZ, USAID, CARE, Gatsby Trust and TechnoServe. The introduction of this requirement is to be welcomed as opposed to the previous approach, namely one that viewed farmers simply as targets of publicprivate interventions. The emphasis placed on organising disparate producers into groups might in fact offer scope for the producers to use voice during negotiations with buyers, as shown by the case of Kevian, and potentially even within the wider partnership.

The opportunity that the GSB Kenya has failed to foster is a closer and more systematic partnership with local authorities and higher-level governmental bodies, as Frynas and Newell (2007: 677) point out 'even in the most dysfunctional African states, with weak go vernment authorities, the state continues to exert an important influence on development'. Incorporating more meaningfully public authorities in the processes of defining how business interests and developmental priorities might be reconciled could potentially contribute to the long-term impact of sustainable business models. For example, in the cases discussed lack of transport, inadequate infrastructures, information and credit were all identified as factors that hindered the furtherance of the partnerships' developmental dimension and inherently called for public policy intervention and the mobilisation of public resources.

\section{Conclusions}


The GSB epitomises an example of proliferating forms of public-private governance, and like some of its counterparts such as the now defunct DFID's Business Linkages Challenge Fund or the Sustainable Agriculture Initiative Platform, its mandate and current global project portfolio place in a unique position to affect the welfare of small-scale agricultural and food producers in LDCs. Notwithstanding the initiative's 'learn as you go' approach, the paper has sought to demonstrate that thus far its degree of inclusiveness has been limited, while from the perspective of the beneficiaries its development impacts have yet to materialise.

The two cases presented in the paper showed that at no point the expected beneficiaries were consulted or included in the processes of deliberation. Furthermore, neither the smallholders in Embu nor the mango growers in Malindi reaped the benefits postulated within the GSB development proposition. The farmers in Embu were caught in between a hostile relationship between a young cooperative and Global Nuts, while the mango growers in Malindi lost their status as beneficiaries because they were located away from Kevian's production facilities. Comparatively the GSB has nurtured very close relationships with the private sector representatives of the Coordinating Group and business partners, and has offered them considerable advantages such as political spaces, networking opportunities, publicity and assistance in conceptualising and co-funding specific projects. Within the context of debates on democratic legitimacy and sustainable and equitable development these asymmetries expose the fragility of the partnership rationale and the practice of public-private partnerships.

The GSB, however, could be perceived more legitimate and even prove to be more effective if all the expected beneficiaries were given more voice in the phases of project selection and implementation. Opening up the GSB's decision-making mechanism to representatives of the beneficiaries, other non-strategic and less complacent 'stakeholders' coupled with the consistent involvement of public authorities could improve the prospects of addressing (some of the) developmental needs of the beneficiaries, and the expectations, roles and responsibilities of different actors within each project. Integrating farmers and other recipients of public-private development assistance within the GSB structures could potentially narrow the participatory gap identified in this research paper, and offer a space for the agency of the (otherwise) politically marginalised - a space where knowledge, values, demands, and objections can be openly articulated.

Within the wider UN family examples of bottom- up engagement mechanisms with farmers groups do exist. The International Fund for Agriculture and Development (IFAD) bi-annual Farmer's Forum is a testimony that attempts to integrate small farmers, groups of producers and governments within policy processes can be attained. This is not to say that participation generates 'win-win' outcomes and eradicates power asymmetries, but that allowing the beneficiaries to actively partake in decision making processes leaves open the possibility for partnerships to become more accountable and less technocratic.

Employment and income generation are some of the postulated benefits that sustainable business models hope to produce but these assumptions need to be verified and followed up while closer attention will progressively need to be placed on the capacity building elements and the quality of employment relationships that 
different partnerships promote, and the wider social investment they might attract. The GSB does not currently have disclosure, monitoring or impact assessment mechanisms, what is known about 'development' primarily comes from the information that lead-businesses disclose, but as the existing partnerships develop and new groups of beneficiaries are identified the UNDP will have to demonstrate how and whether the model works not only to the advantage of private partners but also for those it seeks to lift out of poverty.

\section{Preliminary Acknowledgements}

I would like to thank Peter Utting for encouraging me to write this paper, Craig Murphy and Rorden Wilkinson for reading the paper and providing incisive comments. The paper also benefitted from the questions and comments made by the participants of the Symposium 'Private Governance in the Agro-Food System' held at the University of Münster in April 2008. Last, I would like to express my gratitude to the civil servants, farmers, businesses and NGOs that offered their time to answer my questions.

\section{Bibliography}

Bäckstrand, K. 2006. Democratizing Global Environmental Governance? Stakeholder Democracy after the World Summit on Sustainable Development. European Journal of International Relations 12 (4): 467-498.

Blowfield, M. 2007. Reasons to be cheerful? What we know about csr's impact. Third World Quarterly 28 (4): 683-695.

Brown, O. and C. Sanders. 2007. Global Supply Chains and Smallholder Farmers.

Trade Knowled ge Network, International Institute for Sustainable Development. http://www.iisd.org/PUBLICATIONS/pub.aspx?id=851. Accessed 7 March 2008. Bull, B., Bøäs M. and D. McNeill. 2004. Private Sector Influence in the Multilateral System: A Changing Structure of World Governance?, Global Governance 10: 481498.

Bull, B. and D. McNeill. 2007. Development Issues in Global Governance- PublicPrivate Partnerships and Market Multilateralism. London: Routled ge.

Cox, R. W. 1997. The New Realism: Perspectives on Multilateralism and World Order. Basingstoke: MacMillian.

Day, W., Gandhi S. and J. Giersing. 2005 a. UNDP's Growing Sustainable Business Initiative: From Policies to Action. Alliance 10 (3): 50-52.

Dolan. C. 2005. Fields of Obligation - Rooting ethical sourcing in Kenyan horticulture. Journal of Consumer Culture 5 (3): 365-389.

Dolan, C. and J. Humphrey. 2004. Changing governance patterns in the trade in fresh vegetables between Africa and the United Kingdom. Environment and Planning A 36: 491-509.

Dolan C. and M. Opondo. 2005. Seeking Common Ground: Multistakeholder Initiatives in the Kenya Cut Flower Industry. Journal of Corporate Citizenship 18: 112.

Freeman, A. H., F. Ellis and E. Allison. 2004. Livelihood and Rural Poverty

Reduction in Kenya. Development Policy Review 22 (2): 147-171.

Fuchs, D. 2007. Business Power in Global Governance. Boulder Colorado: Lynne Rienner. 
Gatsby Trust. (n/d). Gatsby in Africa: building local capacities for enterprise and income generation. Occasional Paper.

http://www.gatsby.org.uk/pdfs/GatsbyOP_TP_Margins.pdf. Accessed 7 March 2008 Jenkins, R. 2005. Globalisation, Corporate Responsibility and Poverty. International Affairs 81 (3): 525-540.

McFalls, R. 2007. Testing the Limits of 'Inclusive Capitalism' - A Case Study of the South Africa HP i-Community. Journal of Corporate Citizenship 28: 85-98.

Nelson, J. 2002. Building Partnerships - Cooperation between the United Nations System and the Private Sector. United Nations Department of Public Affairs, New York.

Newel, P. 2005. Citizenship, accountability and community the limits of the CSR agenda. International Affairs 81 (3): 541-557.

Newell, P. and G. Frynas. 2007. Beyond CSR? Business, poverty and social justice: an introduction. Third World Quarterly 28 (4): 669-681.

Odell, J.S. 2004. Case Study Methods in International Political Economy. In Detlef F. Spriz and Yael Wolinsky-Nahmias (Eds), Models, Numbers, and Cases: Methods for Studying International Relations. Ann Arbor: University of Michigan Press, 56-80. Prahalad, C. K. 2005. The Fortune at the Bottom of the Pyramid-Eradicating Poverty through Profits. New Jersey: Wharton School Publishing.

Prieto-Carrón, M., Lund-Thomsen, P., Chan A., Muro A. and C. Bushanan. 2006.

Critical Perspectives on CSR and development: what we know, we don't know and what we need to know. International Affairs 82 (5): 977-987.

Reinicke, W.H. and F.M. Deng. 2000. Critical Choices: The United Nations, networks and the future of global governance. Toronto: International Development Research Council.

Sandbrook, R. 2002. Growing Sustainable Business for Poverty Reduction in Tanzania. http://www.tz.undp.org/publications/GSB_introduction.ppt. Accessed 16 September 2007.

Shamir, Ronen. 2004. The De-Radicalization of Corporate Social Responsibility. Critical Sociology 30 (3): 669-689.

Soederber, S. 2006. Global Governance in Question - Empire, Class and the New Common Sense in Managing North South Relations. London: Pluto Press.

Thomas, C. 2000. Global Governance, Development and Human Security. London: Pluto Press.

UN Commission on the Private Sector and Development. 2004. Unleashing Entrepreneurship - Making Business Work for the Poor. New York: UNDP.

UNDP. 2006. Partnering for Development - Making it Happen. Copenhagen: UNDP Nordic Office. http://www.undp.org/partners/business/UNDP-booklet-web.pdf. Accessed 10 March 2008.

UNDP. 2007. Growing Sustainable Business Initiative Operation Manual - Draft. Volume No. 1, October 2007.

http://europeandcis.undp.org/uploads/public/File/101007_Operations_Manual_draft_f inal(2).pdf. Accessed 5 March 2008.

UNDP Growing Sustainable Business Initiative. 2005. Coordinating Group Meeting Brief Note on the outcome of the $1^{\text {st }}$ Meeting. Nairobi, 26 October.

UNDP Growing Sustainable Business Initiative. 2006 a. Coordinating Group Meeting - Minutes of the $4^{\text {th }}$ Meeting. Nairobi, 6 June.

UNDP Growing Sustainable Business Initiative. 2006 b. Coordinating Group Meeting - Minutes of the $5^{\text {th }}$ Meeting. Nairobi, 17 August. 
UN General Assembly. 2003. Enhanced Cooperation Between the United Nations and All Relevant Partners, in Particular the Private Sector. Report of the UN Secretary General. UN Doc. No. A/58/227, 18 August.

UN Global Compact. 2002. Global Compact Launches Development Initiative at

Summit.

http://www.unglobalcompact.org/Issues/sustainable_development/meetings_and_wor kshops/Global_Compact_Launches_Development.html. Accessed 16 September 2007.

UN Global Compact and UNDP. Growing Sustainable Business for Poverty

Reduction. Available at:

http://www.unglobalcompact.org/docs/issues_doc/7.3/GSB_overview.pdf . Accessed 16 September 2007.

UN Global Compact and UNDP. 2002. Growing Sustainable Business for Poverty Reduction in Tanzania - ToR for the GSB Co-ordinating Group. http://www.tz.undp.org/publications/GSB_draftTOR.pdf . Accessed 20 September 2007.

Utting, P. and A. Zammit. 2006. Beyond Pragmatism, Appraising UN-Business Partnerships. UNRISD, Market, Business and Regulation, Programme Paper No.1. Witte, J. M. and W. Reinicke. 2005. Business Unusual-Facilitating United Nations Reform through Partnerships. New York: United Nations Global Compact Office. World Bank. 2005. Private Sector Involvement as a Vital Factor in Achieving the Millennium Development Goals. Washington D.C.: The International Bank for Reconstruction and Development. http://siteresources.worldbank.org/CGCSRLP/Resources/business_md gs.pdf.

Accessed 10 March 2008.

Zammit, A. 2003. Development at Risk - Rethinking UN-Business Partnerships. Geneva: South Centre and UNRISD.

\section{Annex 1: Growing Sustainable Business Initiative in Kenya Project Portfolio 2005-8}

\begin{tabular}{|c|c|c|c|c|c|}
\hline Date & Project Partners & Project Description & $\begin{array}{l}\text { Development } \\
\text { Objectives }\end{array}$ & $\begin{array}{l}\text { Beneficiaries (Other } \\
\text { than lead company) }\end{array}$ & Progress \\
\hline May 2005 & Grameen, UNDP. & $\begin{array}{l}\text { Introduce a 'Village Phone' } \\
\text { model whereby local } \\
\text { entrepreneurs who purchase a } \\
\text { telecommunication kit from } \\
\text { Grameen and its partners } \\
\text { would provide phone services. }\end{array}$ & $\begin{array}{l}\text { Enable access to mobile } \\
\text { phone technology. }\end{array}$ & $\begin{array}{l}\text { Microfinance Institutions, } \\
\text { Village Operators, local } \\
\text { communities. }\end{array}$ & $\begin{array}{l}\text { De-linked from } \\
\text { GSB Kenya. }\end{array}$ \\
\hline May 2005 & $\begin{array}{l}\text { SC Johnson, } \\
\text { Pyrethrum Board of } \\
\text { Kenya (PBK), } \\
\text { Approtec (now } \\
\text { KickStart). }\end{array}$ & $\begin{array}{l}\text { Attain higher production of } \\
\text { nat ural py rethrum by } \\
\text { increasing quantity and quality. } \\
\text { PBK's role is to provide free } \\
\text { clonal seeds while Approtec } \\
\text { market and sells MoneyMaker } \\
\text { pumps. }\end{array}$ & $\begin{array}{l}\text { Increase the income } \\
\text { raised from the cash } \\
\text { crop. Give farmers access } \\
\text { to irrigation technology } \\
\text { and seeds. }\end{array}$ & $\begin{array}{l}\text { Support } 1 \text { million people } \\
\text { living in } 1 \$ / \text { day. }\end{array}$ & $\begin{array}{l}\text { De-linked from } \\
\text { GSB Kenya/Active }\end{array}$ \\
\hline May 2005 & TetraPak, UNDP. & $\begin{array}{l}\text { Development of a cereal based } \\
\text { nutrit ional milk to be used by } \\
\text { workers, people living with } \\
\text { HIV/AIDS, relief zones, } \\
\text { refugee camps and schools. }\end{array}$ & $\begin{array}{l}\text { Poverty reduction, } \\
\text { development of the } \\
\text { private sector, improved } \\
\text { health and education, } \\
\text { improved trade balance. }\end{array}$ & $\begin{array}{l}\text { Consumers - urban and } \\
\text { rural poor. }\end{array}$ & $\begin{array}{l}\text { De-linked from the } \\
\text { GSB Kenya/ Pilot } \\
\text { project active GSB } \\
\text { Tanzania. }\end{array}$ \\
\hline Summer 2005 & $\begin{array}{l}\text { Export Promotion } \\
\text { Council (EPC), a } \\
\text { European Logistics } \\
\text { Company, an Airline, } \\
\text { Co-op Bank, GTZ, } \\
\text { KGT, UNDP. }\end{array}$ & $\begin{array}{l}\text { Establish cooling facilities in } \\
\text { production areas for perishable } \\
\text { products, refrigerated trucks } \\
\text { and storage facilities to ensure } \\
\text { unbroken cold chains to EU } \\
\text { markets. }\end{array}$ & $\begin{array}{l}\text { Increased income and } \\
\text { employment, higher trade } \\
\text { with the EU. }\end{array}$ & Farmers. & $\begin{array}{l}\text { De-linked from the } \\
\text { GSB Kenya. }\end{array}$ \\
\hline Summer 2005 & $\begin{array}{l}\text { Global Entrepreneurs, } \\
\text { Global Nuts, Mt. }\end{array}$ & $\begin{array}{l}\text { Develop a global supply chain } \\
\text { for macadamia nuts and }\end{array}$ & $\begin{array}{l}\text { Increased income and } \\
\text { employment, higher }\end{array}$ & $\begin{array}{l}\text { Farmers, local processing } \\
\text { plant. }\end{array}$ & Active \\
\hline
\end{tabular}




\begin{tabular}{|c|c|c|c|c|c|}
\hline & Kenya Nuts, UNDP. & $\begin{array}{l}\text { strengthen the domestic nuts } \\
\text { production by working with } \\
\text { farmers and a local processing } \\
\text { plant. }\end{array}$ & exports. & & \\
\hline Summer 2005 & $\begin{array}{l}\text { Vestergaard-Frandsen, } \\
\text { UNDP, }\end{array}$ & $\begin{array}{l}\text { Development of a water } \\
\text { purification tool called Life } \\
\text { Straw, which prevents water } \\
\text { born diseases. The locally } \\
\text { produced straw costs US\$3 and } \\
\text { lasts one year. }\end{array}$ & $\begin{array}{l}\text { Reduce the proportion of } \\
\text { people without access to } \\
\text { safe and drinking water. }\end{array}$ & $\begin{array}{l}\text { Consumers - urban and } \\
\text { rural poor. }\end{array}$ & $\begin{array}{l}\text { De-linked from } \\
\text { GSB Kenya/Active }\end{array}$ \\
\hline Summer 2005 & $\begin{array}{l}\text { Waving } \\
\text { Communications, } \\
\text { UNDP. }\end{array}$ & $\begin{array}{l}\text { Establishing a mobile phone } \\
\text { recycling plant to manufact ure } \\
\text { and assemble mobile phones at } \\
\text { lowering manufacturing costs } \\
\text { than market standards. }\end{array}$ & $\begin{array}{l}\text { Enable access to mobile } \\
\text { phone technology. }\end{array}$ & Urban and rural poor. & $\begin{array}{l}\text { De-linked from the } \\
\text { GSB Kenya. }\end{array}$ \\
\hline Summer 2005 & $\begin{array}{l}\text { D1 Oil, Total, Vanilla } \\
\text { Development } \\
\text { Foundation, UNDP. }\end{array}$ & $\begin{array}{l}\text { Increase the production of } \\
\text { biodisel produced by Jatropha } \\
\text { plants and establish a } \\
\text { distribution net work across } 100 \\
\text { service stations across Kenya. }\end{array}$ & $\begin{array}{l}\text { Higher income and } \\
\text { employment, higher } \\
\text { production capacities, } \\
\text { sustainable fuels. }\end{array}$ & $\begin{array}{l}\text { Jatropha farmers and } \\
\text { biodisel consumers. }\end{array}$ & $\begin{array}{l}\text { De-linked from the } \\
\text { GSB Kenya. }\end{array}$ \\
\hline October 2005 & $\begin{array}{l}\text { Freeplay Energy, Co- } \\
\text { operative Bank, } \\
\text { UNDP. }\end{array}$ & $\begin{array}{l}\text { Freeplay manufact ures } \\
\text { productsthat make use of self- } \\
\text { sufficient energy. } \\
\text { Establishment of an East } \\
\text { Africa distribut or to sell the } \\
\text { productsto retailers who have } \\
\text { been granted a microfinance } \\
\text { loan. The retailer will sell the } \\
\text { products using a two-part tariff } \\
\text { model. }\end{array}$ & $\begin{array}{l}\text { Improved education } \\
\text { through employment } \\
\text { creation and local } \\
\text { economic development. }\end{array}$ & $\begin{array}{l}\text { Rural Communities with } \\
\text { infrequent access to } \\
\text { electricity. }\end{array}$ & $\begin{array}{l}\text { Endorsed by the } \\
\text { GSB } \\
\text { Kenya/Inactive }\end{array}$ \\
\hline October 2005 & $\begin{array}{l}\text { Kevian, Kenya Gatsby } \\
\text { Trust, Africa Insect } \\
\text { Science for Food and } \\
\text { Health (ICIPE), } \\
\text { Ministry of } \\
\text { Agriculture, GTZ, } \\
\text { Kenya Federation of } \\
\text { Agricultural } \\
\text { Producers, UNDP. }\end{array}$ & $\begin{array}{l}\text { Creation of a supply chain for } \\
\text { mangoes to produce locally, } \\
\text { rather than import, } \\
\text { concentrated fruit juice. }\end{array}$ & $\begin{array}{l}\text { Poverty reduction } \\
\text { through employment } \\
\text { creation and local } \\
\text { development. }\end{array}$ & $\begin{array}{l}\text { Small-scale farmers in } \\
\text { Eastern, Central, coastal } \\
\text { and Rift Valley area. }\end{array}$ & Active \\
\hline Oct ober 2005 & $\begin{array}{l}\text { Microsoft East Africa, } \\
\text { International Financial } \\
\text { Corporation (IFC) } \\
\text { SME Solutions } \\
\text { Centre, IFC } \\
\text { Grassroots Business } \\
\text { Organization, Institute } \\
\text { for Development } \\
\text { Studies (Nairobi), } \\
\text { UNDP. }\end{array}$ & $\begin{array}{l}\text { Tailoring Microsoft's Small } \\
\text { Business Account ing - an } \\
\text { existing productivity tool target } \\
\text { application - to suit the specific } \\
\text { needs of SMEs in Kenya. }\end{array}$ & $\begin{array}{l}\text { Poverty reduction } \\
\text { through employment } \\
\text { creation and local } \\
\text { development. }\end{array}$ & $\begin{array}{l}\text { Small and Medium Size } \\
\text { Ent erprises. }\end{array}$ & $\begin{array}{l}\text { Endorsed by the } \\
\text { GSB Kenya/ } \\
\text { Inactive }\end{array}$ \\
\hline December 2005 & Ezipei, UNDP. & $\begin{array}{l}\text { Creation of an automated low- } \\
\text { value financial payment system } \\
\text { for microfinance services. }\end{array}$ & $\begin{array}{l}\text { Poverty reduction } \\
\text { through the provision of } \\
\text { microfinance services. }\end{array}$ & Microfinance Institutions. & $\begin{array}{l}\text { De-linked from the } \\
\text { GSB Kenya. }\end{array}$ \\
\hline December 2005 & $\begin{array}{l}\text { Voxiva, Pride Africa } \\
\text { (Drum Net), UNDP. }\end{array}$ & $\begin{array}{l}\text { Development of an existing } \\
\text { information plat form, which } \\
\text { gives farmers access to market } \\
\text { and financial dat a through } \\
\text { mobile phones rather than the } \\
\text { internet. }\end{array}$ & $\begin{array}{l}\text { Reduce information } \\
\text { asymmetries and reduce } \\
\text { poverty through } \\
\text { increased sales. }\end{array}$ & Farmers. & $\begin{array}{l}\text { De-linked from the } \\
\text { GSB Kenya/Active }\end{array}$ \\
\hline June 2006 & $\begin{array}{l}\text { Co-operative } \\
\text { Insurance Company of } \\
\text { Kenya (CIC), } \\
\text { Corporate Renewal, } \\
\text { Microfinance } \\
\text { Institutions (MFIs), } \\
\text { Nairobi Informal } \\
\text { Sector Confederation, } \\
\text { UNDP. }\end{array}$ & $\begin{array}{l}\text { Make available micro- } \\
\text { insurance services to informal } \\
\text { traders at affordable premiums. }\end{array}$ & $\begin{array}{l}\text { Provide the informal } \\
\text { sector with the protection } \\
\text { against risks that might } \\
\text { lower productivity, } \\
\text { income and circles of } \\
\text { poverty. }\end{array}$ & 15,000 informaltraders. & Active. \\
\hline June 2006 & $\begin{array}{l}\text { Gamewatchers Safari } \\
\text { (Porini), UNDP. }\end{array}$ & $\begin{array}{l}\text { Provide access to water by } \\
\text { drilling boreholes out side an } \\
\text { eco-camp in the Mara region. }\end{array}$ & $\begin{array}{l}\text { Access to safe drinking } \\
\text { water, increased } \\
\text { employment and income } \\
\text { through tourism } \\
\text { development. }\end{array}$ & Local communities. & Active. \\
\hline August 2006 & $\begin{array}{l}\text { Celtel, Psitek, Value } \\
\text { added Services, }\end{array}$ & $\begin{array}{l}\text { Increase the usage of Celtel's } \\
\text { Simu Yetu community }\end{array}$ & $\begin{array}{l}\text { Poverty reduction } \\
\text { through employment }\end{array}$ & $\begin{array}{l}\text { Payphone operat ors and } \\
\text { consumers who benefit }\end{array}$ & Active. \\
\hline
\end{tabular}




\begin{tabular}{|c|c|c|c|c|c|}
\hline & $\begin{array}{l}\text { Packet stream, Pride } \\
\text { Africa, Health Data } \\
\text { System, MFIs, UNDP. }\end{array}$ & $\begin{array}{l}\text { payphones by launching a } \\
\text { next-generation of data-rich } \\
\text { GPRS (GeneralPacket Radio } \\
\text { Service) payphone. }\end{array}$ & $\begin{array}{l}\text { creation (i.e. } 13,500 \text { new } \\
\text { payphone operators) and } \\
\text { local economic } \\
\text { development. }\end{array}$ & $\begin{array}{l}\text { from lower-cost access to } \\
\text { money transfer and other } \\
\text { commercial services. }\end{array}$ & \\
\hline August 2006 & $\begin{array}{l}\text { Suera Flowers, Africa } \\
\text { Now, UNDP. }\end{array}$ & $\begin{array}{l}\text { Develop a supply chain for } \\
\text { Suera flowers, which includes } \\
\text { investment in cold storage, } \\
\text { pack-houses, vehicles, trucks } \\
\text { for collection as well as } \\
\text { financing facilities for farmers. }\end{array}$ & $\begin{array}{l}\text { Poverty reduction } \\
\text { through employment } \\
\text { creation (from the } \\
\text { exist ing } 250 \text { to } 5,000 \\
\text { jobs). Access to export } \\
\text { marketsthrough } \\
\text { certification and quality } \\
\text { controls. }\end{array}$ & Farmers. & Active. \\
\hline 2007 & $\begin{array}{l}\text { Honeycare Africa } \\
\text { (HCA), UNDP. }\end{array}$ & $\begin{array}{l}\text { Encourage small farmersto } \\
\text { begin beekeeping and reach the } \\
\text { consumers at the bottom of the } \\
\text { pyramid by selling } 20 \mathrm{~g} \text { honey } \\
\text { jars in the slum areas in Kenya. }\end{array}$ & $\begin{array}{l}\text { Poverty reduction } \\
\text { through employment } \\
\text { creation and diversified } \\
\text { sources of income. }\end{array}$ & $\begin{array}{l}\text { Small-scale farmers, } \\
\text { beekeepers and } \\
\text { consumers. }\end{array}$ & Active. \\
\hline
\end{tabular}

Source: Compiled by the author from the UNDP GSB, the UNDP GSB Kenya websites and interviews. 